\title{
Impacts of oak deforestation and rainfed cultivation on soil redistribution processes across hillslopes using ${ }^{137} \mathrm{Cs}$ techniques
}

Shamsollah Ayoubi ${ }^{1}$, Nafiseh Sadeghi ${ }^{1}$, Farideh Abbaszadeh Afshar ${ }^{2}$, Mohammad Reza Abdi $^{3}$, Mojtaba Zeraatpisheh ${ }^{4,5^{*}}$ (D) and Jesus Rodrigo-Comino ${ }^{6,7}$

\begin{abstract}
Background: As one of the main components of land-use change, deforestation is considered the greatest threat to global environmental diversity with possible irreversible environmental consequences. Specifically, one example could be the impacts of land-use changes from oak forests into agricultural ecosystems, which may have detrimental impacts on soil mobilization across hillslopes. However, to date, scarce studies are assessing these impacts at different slope positions and soil depths, shedding light on key geomorphological processes.

Methods: In this research, the Caesium-137 $\left({ }^{137} \mathrm{Cs}\right)$ technique was applied to evaluate soil redistribution and soil erosion rates due to the effects of these above-mentioned land-use changes. To achieve this goal, we select a representative area in the Lordegan district, central Iran. ${ }^{137} \mathrm{Cs}$ depth distribution profiles were established in four different hillslope positions after converting natural oak forests to rainfed farming. In each hillslope, soil samples from three depths $(0-10,10-20$, and 20-50 cm) and in four different slope positions (summit, shoulder, backslope, and footslope) were taken in three transects of about $20 \mathrm{~m}$ away from each other. The activity of ${ }^{137} \mathrm{Cs}$ was determined in all the soil samples (72 soil samples) by a gamma spectrometer. In addition, some physicochemical properties and the magnetic susceptibility (MS) of soil samples were measured.
\end{abstract}

Results: Erosion rates reached $51.1 \mathrm{t} \cdot \mathrm{ha}^{-1} \cdot \mathrm{yr}^{-1}$ in rainfed farming, whereas in the natural forest, the erosion rate was $9.3 \mathrm{t} \cdot \mathrm{ha}^{-1} \cdot \mathrm{yr}^{-1}$. Magnetic susceptibility was considerably lower in the cultivated land $\left(X_{\mathrm{hf}}=43.5 \times 10^{-8} \mathrm{~m}^{3} \cdot \mathrm{kg}^{-1}\right)$ than in the natural forest $\left(X_{h f}=55.1 \times 10^{-8} \mathrm{~m}^{3} \cdot \mathrm{kg}^{-1}\right)$. The lower soil erosion rate in the natural forest land indicated significantly higher MS in all landform positions except at the summit one, compared to that in the rainfed farming land. The shoulder and summit positions were the most erodible hillslope positions in the natural forest and rainfed farming, respectively.

Conclusions: We concluded that land-use change and hillslope positions played a key role in eroding the surface soils in this area. Moreover, land management can influence soil erosion intensity and may both mitigate and amplify soil loss.

Keywords: Land-use change, Soil redistribution, Topographical changes, Radionuclide, Rainfed farming, Deforestation

\footnotetext{
* Correspondence: mojtaba.zeraatpisheh@henu.edu.cn

${ }^{4}$ Henan Key Laboratory of Earth System Observation and Modeling, Henan

University, Kaifeng 475004, China

${ }^{5}$ College of Environment and Planning, Henan University, Kaifeng 475004,

China

Full list of author information is available at the end of the article
}

\section{Springer Open}

(c) The Author(s). 2021 Open Access This article is licensed under a Creative Commons Attribution 4.0 International License, which permits use, sharing, adaptation, distribution and reproduction in any medium or format, as long as you give appropriate credit to the original author(s) and the source, provide a link to the Creative Commons licence, and indicate if changes were made. The images or other third party material in this article are included in the article's Creative Commons licence, unless indicated otherwise in a credit line to the material. If material is not included in the article's Creative Commons licence and your intended use is not permitted by statutory regulation or exceeds the permitted use, you will need to obtain permission directly from the copyright holder. To view a copy of this licence, visit http://creativecommons.org/licenses/by/4.0/. 


\section{Introduction}

As one of the main components of land-use change, deforestation is considered the greatest threat to humankind because it can affect global environmental diversity (Akter et al. 2018; Al Sayah et al. 2019). To date, forests still cover about $30 \%$ of the world's surface area, but they disappear at an alarming rate (Curtis et al. 2018). Since humans started cutting down forests, recent studies estimated that $46 \%$ of trees had been felled (Ehrenberg 2015). Nowadays, there are 14.38 million hectares of forest in Iran, covering $7.8 \%$ of the country's total area, reaching the Zagros forests with 1.5 million hectares the $2 \%$ of Iran's forests (FRWO 2018). However, Zagros forests are suffering deforestation and burnt dramatically, and land-use changes to cultivated and urban areas are increasing (Mojiri et al. 2012; Kelishadi et al. 2014; Alidoust et al. 2018).

Such land-use change can influence multiple parameters that control the hydrological and geomorphological transport processes such as soil infiltration capacity, soil erodibility, surface roughness, and the local capacity to store water and sediment (Hill et al. 2008; Bajocco et al. 2012; Kavian et al. 2017; Taghizadeh-Mehrjardi et al. 2019). Land-use changes are a worldwide issue that commonly leads to land degradation, mainly modifying some soil quality parameters (Nabiollahi et al. 2020; Zeraatpisheh et al. 2020). Moreover, land-use change has a significant contribution to greenhouse gas emissions, and it was accounted for $12.5 \%$ of carbon emissions from 1990 to 2010 (Houghton et al. 2012) and one-third of total anthropogenic carbon discharges over the last 150 years (Quesada et al. 2018).

Soils, among other Earth's spheres, are highly affected, and increasing awareness by stakeholders, rural inhabitants, and policymakers is vital to reduce negative and irreversible impacts (Rodrigo-Comino et al. 2020a). In the context of global climate change and environmental degradation, protecting soils as a non-renewable resource must be a worldwide concern (Celik 2005; Lal 2015; Orgiazzi et al. 2018). Human activities have been the primary drivers of environmental change over recent years by transforming natural ecosystems into agricultural landscapes (Chauchard et al. 2007). Due to agricultural deforestation, the conversion of rangeland into croplands is a local and global environmental concern (Foley et al. 2005), resulting in altered soil properties and soil penetration rates and changed soil physical characteristics that ultimately increase soil erosion ( $\mathrm{Li}$ et al. 2007; Nabiollahi et al. 2020; Zeraatpisheh et al. 2020).

Soil erosion research offers an opportunity to study the effect of land-use changes on degradation processes (Jordan et al. 2005; Szilassi et al. 2006; Ayoubi et al. 2018). Soil erosion is a major environmental issue after drastically land-use changes, especially after deforestation on hilly lands or abandonment. In qualitative terms, soil erosion is a multifactorial phenomenon driven by several key variables such as climate, soil properties, topography, and land management (Kosmas et al. 1995; Novara et al. 2015; Taghizadeh-Mehrjardi et al. 2019; Rodrigo-Comino et al. 2020b). The degree of human impact on each of these factors varies significantly depending on the major role of each one. Therefore, it is vital to use methods and perform studies able to detect and assess the intensity of each environmental factor.

One of the artificial radio-isotope used as a tracer to analyze soil redistribution trends and measure soil degradation rates is Caesium-137 $\left({ }^{137} \mathrm{Cs}\right) .{ }^{137} \mathrm{Cs}$ is a byproduct of nuclear weapons tests that took place in the 1950s and 60s. This radio-isotope enters the earth's surface from the atmosphere through wet and dry deposition (mostly by wet deposition (i.e., precipitation)) (Elliott et al., 1990). The specific characteristic of ${ }^{137} \mathrm{Cs}$ that only adsorbed by soil particles, physically migrate with soil particles, and are rarely carried by rainwater or taken up by plants generated an appropriate potential for this radio-isotope to use soil loss process measurements (Hu and Zhang 2019). The successful use of ${ }^{137} \mathrm{Cs}$ to document rates of soil loss has now been for a wide variety of environments (Walling and Quine 1991; Ritchie and Ritchie 2007; Sac et al. 2008; Abbaszadeh Afshar et al. 2010; Ayoubi et al. 2012a; Nosrati et al. 2015; Meliho et al. 2019). However, the use of the ${ }^{137} \mathrm{Cs}$ to monitor soil erosion and investigate the effects of land-use changes on of ${ }^{137} \mathrm{Cs}$ is relatively mature $(\mathrm{Hu}$ and Zhang 2019).

Several decades of severe rainfed agriculture in the Zagros Mountains in Iran and afterward land abandonment have dramatically changed land-use and land cover (Naghipour et al. 2016; Saedi et al. 2016; Zebari et al. 2019). Over recent decades, the natural forest land conversion into agricultural lands has increased the surfaces prone to erosion. The difficulties that the land conversions have created are exclusively significant in mountainous areas and regions with unfavorable environmental conditions (MacDonald et al. 2000). In the Zagros Mountains, for example, where the natural forest lands have been gradually cleared and converted to rainfed agriculture (Ayoubi et al. 2012b). These disturbances result in losses of soil nutrients and diminished long-term fertility of the soil (Bakhshandeh et al. 2019; Ajami et al. 2020). It seems inappropriate land-use change; improper cultivation activities are significant factors in severe soil erosion in the Zagros forests for a long time. However, studies conducted assessing these issues are scarce to date. Therefore, the main goals of the current study are to (i) evaluate the influences of land-use change on soil physical, chemical, and magnetic attributes and (ii) determine the impacts of land-use 
change on soil redistribution and erosion by using the ${ }^{137} \mathrm{Cs}$ technique at different hillslope positions. To achieve these goals, we selected a representative area located in the Lordegan district of Cheharmahal and Bakhtiari Province, western Iran. Therefore, the findings of this research could shed light on new advances related to the knowledge about soil erosion and the negative impacts of land-use changes, especially from oak forests to rainfed farming.

\section{Materials and methods}

\section{Study site and sampling area}

The studied area is located in the Lordegan region of Cheharmahal and Bakhtiari Province, west of Iran, at $51^{\circ} 48^{\prime} \mathrm{E}$ longitudes and $31^{\circ} 37^{\prime} \mathrm{N}$ latitudes (Fig. 1). The average annual precipitation and temperature of the region are $572 \mathrm{~mm}$ and $15.5^{\circ} \mathrm{C}$, respectively (Chaharmahal and Bakhtiari Meteorological Administration 2019). The study area has Xeric soil moisture and Thermic temperature regimes (Soil Survey Staff 2010). The average elevation of the studied area is $1700 \mathrm{~m}$ a.s.l. The vegetation of the area is generally oak forests (Quercus brantii and Quercus infectoria), and species such as Astragalus sp. and Mucronata sp. covered the region.

Two paired-hillslopes were selected with similar elevation and slope gradients but with different land-uses, a natural oak forest and rainfed farming. In each land-use type, soil cores were collected from a plot with dimensions of $20 \mathrm{~m} \times 20 \mathrm{~m}$. The soil was sampled at different depths $(0-10,10-20$, and $20-50 \mathrm{~cm})$ in four different topographical positions, including the summit, shoulder, backslope, and footslope in three transects $20 \mathrm{~m}$ away from each other in selected hillslopes. The reference soil samples were collected from an adjacent site (less than $1000 \mathrm{~m}$ away), the summit position of an oak forest land with relatively high soil development features and a stable state with minimum human disturbance in recent decades. Additionally, two reference soil profiles were also excavated, and soil samples were taken at several depths $(0-10,10-20,20-30$, and $30-50 \mathrm{~cm})$. Then, at

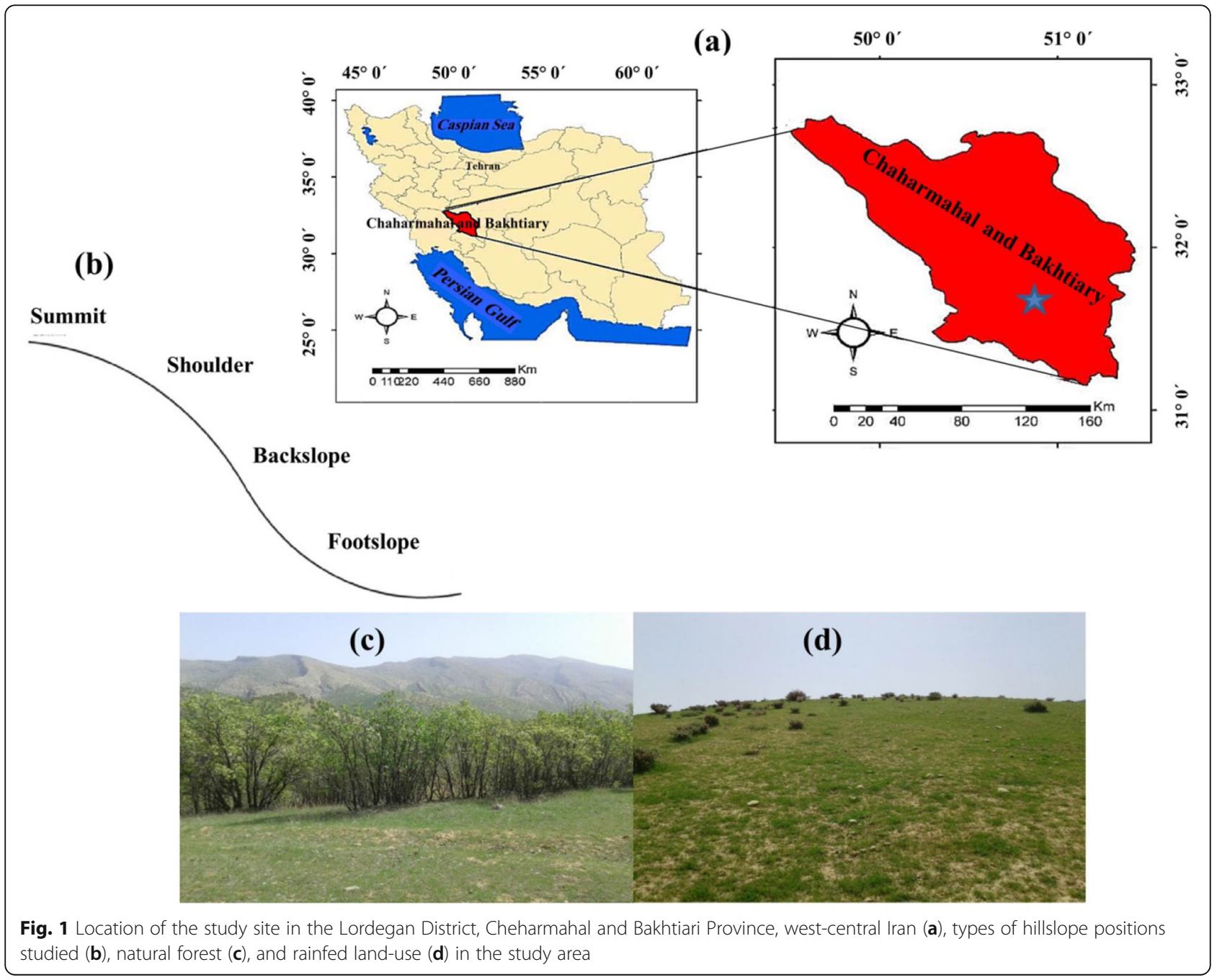


the reference location, the vertical distribution of ${ }^{137} \mathrm{Cs}$ was determined.

\section{Laboratory analysis and ${ }^{137} \mathrm{Cs}$ measurements}

Before the laboratory analysis, the air-dried soil samples were crushed, homogenized, and passed through a 2$\mathrm{mm}$ sieve. From June to July 2018, a total of 72 soil samples (two land-use types $\times$ three replicates per sample plots $\times$ three soil depth classes $\times$ four hillslope positions) were collected within the studied area. In 2018, at the Isfahan University of Iran, soil samples (500 g) were placed in Marinelli beakers and sealed for ${ }^{137} \mathrm{Cs}$ analysis. The ${ }^{137} \mathrm{Cs}$ activity (Bq. $\mathrm{kg}^{-1}$ ) was measured from the net area under the full-energy peak at $662 \mathrm{keV}$ (ISO 119291 , 2000) using gamma spectroscopy with a highresolution germanium detector. The reference material No. IAEA-375 obtained from Analytical Quality Control Services, International Atomic Energy Agency, was used for quality control. The count time was approximately $80,000 \mathrm{~s}$, and the counting error was kept at $<10 \%$ and at the 95\% confidence level. The ${ }^{137} \mathrm{Cs}$ activities $\left(\mathrm{Bq} \cdot \mathrm{kg}^{-1}\right)$ were converted to area activities $\left(\mathrm{Bq} \cdot \mathrm{m}^{-2}\right.$ ) (Walling et al. 2002).

The core method (Blake and Hartge 1986) and wet combustion method (Nelson and Sommers 1996) were used to determine soil bulk density and soil organic matter (SOM) concentration, respectively. The Kjeldahl digestion method was used to determine the total nitrogen (TN) (Bremmer and Mulvaney 1982). Electrical conductivity (EC) was determined in the extract using a conductivity meter (Rhoades 1982). Extractable potassium $\left(\mathrm{K}_{\text {ava }}\right)$ was measured using $1 \mathrm{~mol} \cdot \mathrm{L}^{-1}$ ammonium acetate as the extractant (Richards 1954). The pipette method (Gee and Bauder 1986) was applied to measure soil particle size distributions. Bernard's calcimeter method was used to measure calcium carbonate equivalent (CCE) content (Black et al. 1965). By using a Bartington MS2 dual-frequency sensor at low frequency $\left(X_{\mathrm{lf}}\right)(0.47 \mathrm{kHz})$, high frequency $\left(\chi_{\mathrm{hf}}\right)(4.7 \mathrm{kHz})$, dependent frequency $\left(\chi_{\mathrm{fd}}\right)$, and the magnetic susceptibility (MS) were measured in a four-dram clear plastic vial $(2.3 \mathrm{~cm}$ diameter) using approximately $10 \mathrm{~g}$ of soil.

\section{Soil redistribution calculation}

Several different techniques have been applied to convert ${ }^{137} \mathrm{Cs}$ measurements to quantitative estimates of soil erosion and deposition rates (Walling and He 1999; Walling and He 2000). By using the Simplified Mass Balance Model (SMBM), we decide to use the conversion of ${ }^{137} \mathrm{Cs}$ areal activities into soil redistribution rates (t.ha ${ }^{-1}$. $\mathrm{yr}^{-1}$ ) (Walling and He 1999; Walling et al. 2002; Zhang et al. 2008).

\section{Statistical analyses}

Descriptive and correlations among the variables were determined. The mean values of the ${ }^{137} \mathrm{Cs}$, soil physicochemical properties, magnetic measures of two landuses, and four hillslope positions were calculated. All statistical analyses, including the LSD test (test of significance of differences among the mean values) and correlation analyses, were performed using SPSS 17.0 (IBM, USA) software. Dexter et al. (2008) proposed several equations (Eqs. 1-4) to calculate complexed and noncomplexed organic carbon (OC) and clay. Then, the additional amount of complexed $\mathrm{OC}$, which could be stored in the soil, was estimated using Eq. 5:

$$
\begin{aligned}
& \mathrm{CC}=(n \mathrm{OC}) \text { if }(n \mathrm{OC}<\text { clay }) \text {, else } \mathrm{CC}=\text { clay } \\
& \mathrm{NCC}=(\text { clay }-\mathrm{CC}) \text { if }(\text { clay }-\mathrm{CC})>0, \text { else NCC } \\
& =0 \\
& \mathrm{COC}=\mathrm{OC} \text { if } \mathrm{OC}<(\text { clay } / n), \text { else } \mathrm{COC} \\
& =(\text { clay } / n) \\
& \mathrm{NCOC}=\mathrm{OC}-\mathrm{COC} \text { if }(\mathrm{OC}-\mathrm{COC}) \\
& >0 \text {, else } \mathrm{NCOC}=0 \\
& \mathrm{PAOC}=(\mathrm{CMAX}-\mathrm{COC}) \text { if }(\mathrm{CMAX}-\mathrm{COC}) \\
& >0 \text {, else } \mathrm{PAOC}=0
\end{aligned}
$$

where CC and NCC are complexed and noncomplexed clays $\left(\mathrm{g} \cdot \mathrm{kg}^{-1}\right), \mathrm{COC}$ and $\mathrm{NCOC}$ represent complexed and non-complexed organic carbons $\left(\mathrm{g} \cdot \mathrm{kg}^{-1}\right)$, respectively, and $n$ means the ratio of clay to OC, where clay is assumed to be saturated with $\mathrm{OC}$, which is considered equal to 10 (Dexter et al. 2008). Therefore, saturation line was defined by $\mathrm{COC}=\mathrm{Clay} / n$ (i.e., $n=10$ ). PAOC $\left(\mathrm{g}^{\mathrm{kg}} \mathrm{kg}^{-1}\right)$ is the potential additional complexed $\mathrm{OC}$ which indicates the potential capacity for sequestering carbon, and CMAX $\left(\mathrm{g} \cdot \mathrm{kg}^{-1}\right)$ is the maximum possible amount of complexed OC according to clay $/ n$ ( $n=$ 10) (Dexter et al. 2008).

\section{Results and discussion}

\section{Specific results per land-use and hillslope position}

Table 1 presents the descriptive statistics of ${ }^{137} \mathrm{Cs}$ measurements, physicochemical parameters, and soil magnetic parameters in the studied two land-uses. In the natural forest and the rainfed farming, the coefficient of variation $(\mathrm{CV})$ of the ${ }^{137} \mathrm{Cs}$ contents was $35.7 \%$ and $30.8 \%$, respectively. Abbaszadeh et al. (2010) and Ayoubi et al. (2012a) reported a CV value of $50.0 \%$ and $103.9 \%$ for the ${ }^{137} \mathrm{Cs}$ inventory under rainfed farming and the hilly regions in western Iran, respectively. Consistent with Wilding (1985) for CV classification, ${ }^{137} \mathrm{Cs}$, TN, and clay in the natural oak forest and SOM, $\mathrm{P}_{\text {ava }}$, and clay in the rainfed farming land-uses were classified as 
Table 1 Descriptive statistics for ${ }^{137} \mathrm{C}$, soil physicochemical properties, and magnetic parameters in the different land-uses $(N=72)$

\begin{tabular}{|c|c|c|c|c|c|c|c|c|c|}
\hline Land-use & Variables & Unit & Mean & Min & Max & SD & CV & Skewness & Kurtosis \\
\hline \multirow[t]{15}{*}{ Oak forest } & ${ }^{137} \mathrm{CS}$ & $\mathrm{Bq} \cdot \mathrm{m}^{-2}$ & 516.5 & 140.8 & 1399.2 & 310.6 & 35.7 & 1.2 & 1.7 \\
\hline & SOM & $\%$ & 1.7 & 0.6 & 3.2 & 0.6 & 32.1 & 0.7 & 0.6 \\
\hline & CCE & $\%$ & 37.9 & 11 & 68.5 & 12.3 & 22.8 & 0.2 & 0.05 \\
\hline & $\mathrm{TN}$ & $\%$ & 0.1 & 0.2 & 0.6 & 0.1 & 131.9 & 4 & 16.8 \\
\hline & $P_{a v a}$ & $\mathrm{mg} \cdot \mathrm{kg}^{-1}$ & 63.1 & 39 & 124 & 20 & 32 & 1 & 1 \\
\hline & $\mathrm{K}_{\mathrm{ava}}$ & $\mathrm{mg} \cdot \mathrm{kg}^{-1}$ & 230.3 & 101.6 & 381 & 74.5 & 23 & 0.1 & -0.7 \\
\hline & EC & $d S \cdot m^{-1}$ & 169 & 136 & 255.5 & 25.4 & 13.3 & 1.4 & 2.5 \\
\hline & $\mathrm{pH}$ & - & 7.65 & 7.3 & 7.9 & 0.1 & 1.2 & -0.7 & -0.7 \\
\hline & Clay & $\%$ & 20.8 & 0.8 & 41.6 & 13.38 & 53.9 & -0.04 & -1.7 \\
\hline & Silt & $\%$ & 66.8 & 50.3 & 90.9 & 13.8 & 20.7 & 0.46 & -1.3 \\
\hline & Sand & $\%$ & 12.4 & 5.9 & 33.3 & 5.9 & 35 & 1.5 & 3.1 \\
\hline & $\mathrm{BD}$ & $\mathrm{g} \cdot \mathrm{cm}^{-3}$ & 1.2 & 1.1 & 1.3 & 0.1 & 5.8 & 0.3 & 0.3 \\
\hline & $X_{\text {If }}$ & $10^{-8} \mathrm{~m}^{3} \cdot \mathrm{kg}^{-1}$ & 58.2 & 28.2 & 101.7 & 18.2 & 17.2 & 0.6 & -0.3 \\
\hline & $X_{\mathrm{hf}}$ & $10^{-8} \mathrm{~m}^{3} \cdot \mathrm{kg}^{-1}$ & 55.1 & 26.6 & 94.7 & 16.7 & 16.9 & 0.5 & -0.3 \\
\hline & $X_{\mathrm{fd}}$ & $\%$ & 5.2 & 3.3 & 7.7 & 1.3 & 10.5 & 0.6 & -0.9 \\
\hline \multirow[t]{15}{*}{ Rainfed farming } & ${ }^{137} \mathrm{CS}$ & $\mathrm{Bq} \cdot \mathrm{m}^{-2}$ & 285.6 & 102.8 & 929.1 & 206.7 & 30.8 & 1.3 & 2.3 \\
\hline & SOM & $\%$ & 1.1 & 0.4 & 2.5 & 0.4 & 37.7 & 1.2 & 1.5 \\
\hline & CCE & $\%$ & 41.59 & 23.5 & 72.5 & 8.8 & 20.5 & 1.1 & 3.2 \\
\hline & $\mathrm{TN}$ & $\%$ & 0.05 & 0.02 & 0.05 & 0.01 & 33.2 & 0.5 & 0.5 \\
\hline & $P_{a v a}$ & $\mathrm{mg} \cdot \mathrm{kg}^{-1}$ & 71.8 & 32.6 & 248.3 & 42.9 & 59.6 & 2.8 & 8.6 \\
\hline & $\mathrm{K}_{\mathrm{ava}}$ & $\mathrm{mg} \cdot \mathrm{kg}^{-1}$ & 192.9 & 114.2 & 312.3 & 51.1 & 24.8 & 0.6 & -0.1 \\
\hline & EC & $d S \cdot m^{-1}$ & 157.4 & 126.9 & 207.8 & 21.2 & 12.7 & 0.6 & -0.2 \\
\hline & $\mathrm{pH}$ & - & 7.87 & 7.6 & 7.9 & 0.07 & 0.9 & 0.8 & 1.3 \\
\hline & Clay & $\%$ & 21.8 & 5.6 & 56.8 & 14.9 & 58.5 & 0.7 & -0.2 \\
\hline & Silt & $\%$ & 67.4 & 34.7 & 87.4 & 14.7 & 21.8 & -0.5 & -0.2 \\
\hline & Sand & $\%$ & 10.1 & 5.2 & 20.4 & 4.3 & 33.2 & 1.3 & 0.7 \\
\hline & $\mathrm{BD}$ & $\mathrm{g} \cdot \mathrm{cm}^{-3}$ & 1.2 & 1.1 & 1.3 & 0.1 & 4.2 & 0.9 & 1.3 \\
\hline & $X_{\text {If }}$ & $10^{-8} \mathrm{~m}^{3} \cdot \mathrm{kg}^{-1}$ & 47.8 & 32.1 & 66.2 & 7.3 & 15.9 & 0.8 & 0.5 \\
\hline & $x_{\mathrm{hf}}$ & $10^{-8} \mathrm{~m}^{3} \cdot \mathrm{kg}^{-1}$ & 43.5 & 30.2 & 61.8 & 6.7 & 15.3 & 0.8 & 0.5 \\
\hline & $x_{\mathrm{fd}}$ & $\%$ & 4.9 & 3.1 & 6.7 & 0.9 & 18.9 & 0.04 & -0.6 \\
\hline
\end{tabular}

Min Minimum, Max Maximum, CV Coefficient of variation, SOM Soil organic matter, CCE Calcium carbonate, TN Total nitrogen, $P_{\text {ava }}$ available phosphorus, $K_{a v a}$ available potassium, EC Electrical conductivity, $\mathrm{pH}$ Soil acidity, $B D$ bulk density, $X_{\mathrm{lf}} \mathrm{MS}$ at low frequency, $X_{\mathrm{hf}} \mathrm{MS}$ at high frequency, $X_{\mathrm{fd}}$ dependent frequency MS

highly variable $(C V>0.35)$. Whereas SOM, CCE, $\mathrm{P}_{\mathrm{ava}}$, $K_{\text {ava }}$, slit, sand, $\chi_{\mathrm{lf}}$, and $\chi_{\mathrm{hf}}$ in the forest land-use, and ${ }^{137} \mathrm{Cs}, \mathrm{CCE}, \mathrm{TN}, \mathrm{K}_{\mathrm{ava}}$, slit, sand, $\chi_{\mathrm{lf}}, \chi_{\mathrm{hf}}$ and $\chi_{\mathrm{fd}}$ in the rainfed farming land-uses were classified as moderately variable $(0.15<\mathrm{CV}<0.35)$. Other parameters were classified as a low variable in the two land-uses. These findings indicate substantial heterogeneity in the soil properties distribution caused by soil erosion and deposition along with the hillslope positions and different land-uses.

The mean inventories of ${ }^{137} \mathrm{Cs}$ achieved in the oak forest soils varied from 140.8 to $1399.2 \mathrm{~Bq} \cdot \mathrm{m}^{-2}$. On the other hand, in the rainfed farming soil, the results ranged from 102.8 to $929.1 \mathrm{~Bq} \cdot \mathrm{m}^{-2}$ (Table 1). We observed that the spatial distribution of ${ }^{137} \mathrm{Cs}$ showed higher variability in the oak forest soils (higher CV), possibly due to susceptibility to being eroded by the rainfall and vegetation cover degree, which use to be more elevated in forestry areas than in the cultivated ones with bare soils. The distribution of ${ }^{137} \mathrm{Cs}$ was significantly correlated with plant harvest, vegetation type, residual cover, soil properties, and microtopography (Table 1, Fig. 3). In Fig. 3, the main reason for the irregular distribution of ${ }^{137} \mathrm{Cs}$ in rainfed farming land-use can be related to soil management applied to agricultural fields, which leave the soils bare and applied intense tillage practices (Abbaszadeh et al. 2010). Therefore, since there are no differences between precipitation and elevation in 
the studied sites, it can be concluded that the main reason for ${ }^{137} \mathrm{Cs}$ variation and its redistribution could be the agricultural practices when the rainfed farming soils are compared to the oak forest soils.

In rainfed farming, the lowest and highest $\mathrm{CV}$ values for the soil chemical properties were attributed to $\mathrm{pH}$ $(0.07 \%)$ and $\mathrm{P}_{\mathrm{ava}}$ (59.6\%), respectively. On the other hand, in the natural forest, the lowest and highest CV values for the soil chemical properties were ascribed to $\mathrm{pH}(0.1 \%)$ and TN (131.9\%), respectively. In general, the high variance for the chosen soil properties in the hilly area of the studied site suggested a possible redistribution of the soil during the long-term cultivation of the rainfed land and natural soil detachment and deposition at different locations of the hillslope (Jones et al. 2008). This agrees with other agricultural lands such as steep vineyards where tillage and the use of herbicides leaving the soil bare can change soil erosion rates and, subsequently, soil properties among hillslope positions (Rodrigo-Comino et al. 2016; Rodrigo-Comino et al. 2017). However, when the inclination factor is reduced to the minimum, other authors used rainfall simulators also in vineyards, which could not confirm this premise: differences among hillslope positions (Rodrigo-Comino et al. 2018; Cerdà et al. 2020).

\section{Relationships between ${ }^{137} \mathrm{Cs}$, MS, and soil properties}

The relationships between selected soil properties and ${ }^{137} \mathrm{Cs}$ inventory in different land-uses are shown in Table 2. The ${ }^{137} \mathrm{Cs}$ inventory showed consistent significant correlation coefficients with $\mathrm{K}_{\mathrm{ava}}, \mathrm{CCE}, \chi_{\mathrm{lf}}, \chi_{\mathrm{hf}}$, and clay in oak forest soils and significant correlation

Table 2 Correlation coefficients among ${ }^{137} \mathrm{Cs}$ inventory and selected soil properties in the study area

\begin{tabular}{lll}
\hline Variable & $\begin{array}{l}\text { Oak forest } \\
\text { Cs-137 }\end{array}$ & $\begin{array}{l}\text { Rainfed farming } \\
\text { Cs-137 }\end{array}$ \\
\hline SOM & 0.301 & 0.020 \\
Kava & $0.687^{\mathrm{b}}$ & -0.130 \\
$\mathrm{EC}$ & 0.135 & 0.122 \\
$\mathrm{pH}$ & 0.279 & -0.082 \\
$\mathrm{CCE}$ & $0.572^{\mathrm{b}}$ & $0.382^{\mathrm{a}}$ \\
$\mathrm{TN}$ & 0.083 & -0.207 \\
$\mathrm{BD}$ & 0.239 & -0.329 \\
Pava & -0.055 & $0.345^{\mathrm{a}}$ \\
$X_{\text {If }}$ & $0.780^{\mathrm{b}}$ & -0.325 \\
Xhf & $0.776^{\mathrm{b}}$ & $0.334^{\mathrm{a}}$ \\
Sand & 0.275 & $-0.345^{\mathrm{a}}$ \\
Clay & $-0.399^{\mathrm{a}}$ & $0.374^{\mathrm{a}}$ \\
\hline
\end{tabular}

SOM Soil organic matter, CCE Calcium carbonate, TN Total nitrogen, $P_{\text {ava }}$ available phosphorus, $K_{\text {ava }}$ available potassium, $E C$ Electrical conductivity, $\mathrm{pH}$ Soil acidity, $B D$ bulk density, $X_{\text {If }}$ MS at low frequency, $X_{\mathrm{hf}} \mathrm{MS}$ at high frequency

${ }^{\mathrm{a}}$ and ${ }^{\mathrm{b}}$ stand for significance at probability levels of 0.05 and 0.01 , respectively coefficients with $\mathrm{P}_{\mathrm{ava}}, \mathrm{CCE}, \chi_{\mathrm{hf}}$, sand, and clay in rainfed farming soils. Moreover, in the oak forest, significant positive correlation coefficients between ${ }^{137} \mathrm{Cs}$ and $\mathrm{K}_{\text {ava }}$ $(r=0.69, p<0.01),{ }^{137} \mathrm{Cs}$ and CCE $(r=0.57, p<0.01)$, and ${ }^{137} \mathrm{Cs}$ and $\chi_{\mathrm{If}}(r=0.78, p<0.01)$, and ${ }^{137} \mathrm{Cs}$ and $\chi_{\mathrm{hf}}$ $(r=0.78, p<0.01)$ were observed (Table 2$)$. The negative significant correlation coefficient between ${ }^{137} \mathrm{Cs}$ and clay content $(r=-0.40, p<0.05)$ was achieved (Table 2) for the oak forest. The ${ }^{137} \mathrm{Cs}$ inventory showed consistent significant correlation coefficients with CCE $(r=0.38$, $p<0.05), \mathrm{P}_{\mathrm{ava}}(r=0.35, p<0.05), \chi_{\mathrm{hf}}(r=0.33, p<0.05)$, clay $(r=0.37, p<0.05)$ and sand $(r=-0.35, p<0.05)$, in rainfed farming land-uses. The highest correlation coefficient for ${ }^{137} \mathrm{Cs}$ was observed with $\chi_{\mathrm{lf}}$ and $\chi_{\mathrm{hf}}$ in oak forest land-uses. These ${ }^{137} \mathrm{Cs}$ correlations with soil physicochemical properties indicated that soil erosion and deposition processes could partially regulate the ${ }^{137} \mathrm{Cs}$ variability within the study sites for the selected soil properties (de Neergaard et al. 2008; Olson et al. 2013). In other words, certain soil properties such as soil nutrients, SOM, and magnetic minerals, and ${ }^{137}$ Cs inventory were related to detachment and accumulation of fine particles are regulated simultaneously along the hillslope (Fu et al. 2009; Wakiyama et al. 2010; Li et al. 2017). This outcome revealed that the effects of natural factors on soil erosion rates and other factors, such as the role of land-use types and human activity, could affect the local soil erosion.

\section{${ }^{137} \mathrm{Cs}$ inventory and soil redistribution assessment}

The characteristic of reference sampling locations, including ${ }^{137} \mathrm{Cs}$ depth profiles and their inventories, are given in Fig. 2. In the topsoil layer $(0-10 \mathrm{~cm})$, a significant volume of activity of ${ }^{137} \mathrm{Cs}$ was concentrated and decreased with depth. The mean value of ${ }^{137} \mathrm{Cs}$ inventory obtained from the two reference sites was 978 $\mathrm{Bq} \cdot \mathrm{m}^{-2}$, which is consistent with another study from western Iran with $2120 \mathrm{~Bq} \cdot \mathrm{m}^{-2}$ (Abbaszadeh Afshar et al. 2010), $2067 \mathrm{~Bq} \cdot \mathrm{m}^{-2}$ (Rahimi et al. 2013), and 878 $\mathrm{Bq} \cdot \mathrm{m}^{-2}$ (Bazshoshtari et al. 2016) inventory of soils.

The vertical distribution of ${ }^{137} \mathrm{Cs}$ values in the rainfed farming and natural forest sites for four different hillslopes positions was showed in Fig. 3. A significant amount of ${ }^{137} \mathrm{Cs}$ activity was concentrated in the topsoil layer $(0-10 \mathrm{~cm})$ in oak forest land-use (Fig. 3), and the profile on the summit and shoulder positions showed a near-exponential decline in ${ }^{137} \mathrm{Cs}$ activity with a depth that indicated undisturbed soils in nature forest land-use (Fig. 3a and b). Several studies also reported a high concentration of ${ }^{137} \mathrm{Cs}$ activity in the upper soil layers than the lower ones (Abbaszadeh Afshar et al. 2010; Ayoubi et al. 2012a; Rahimi Ashjerdi et al. 2013; Bazshoushtari et al. 2016). 


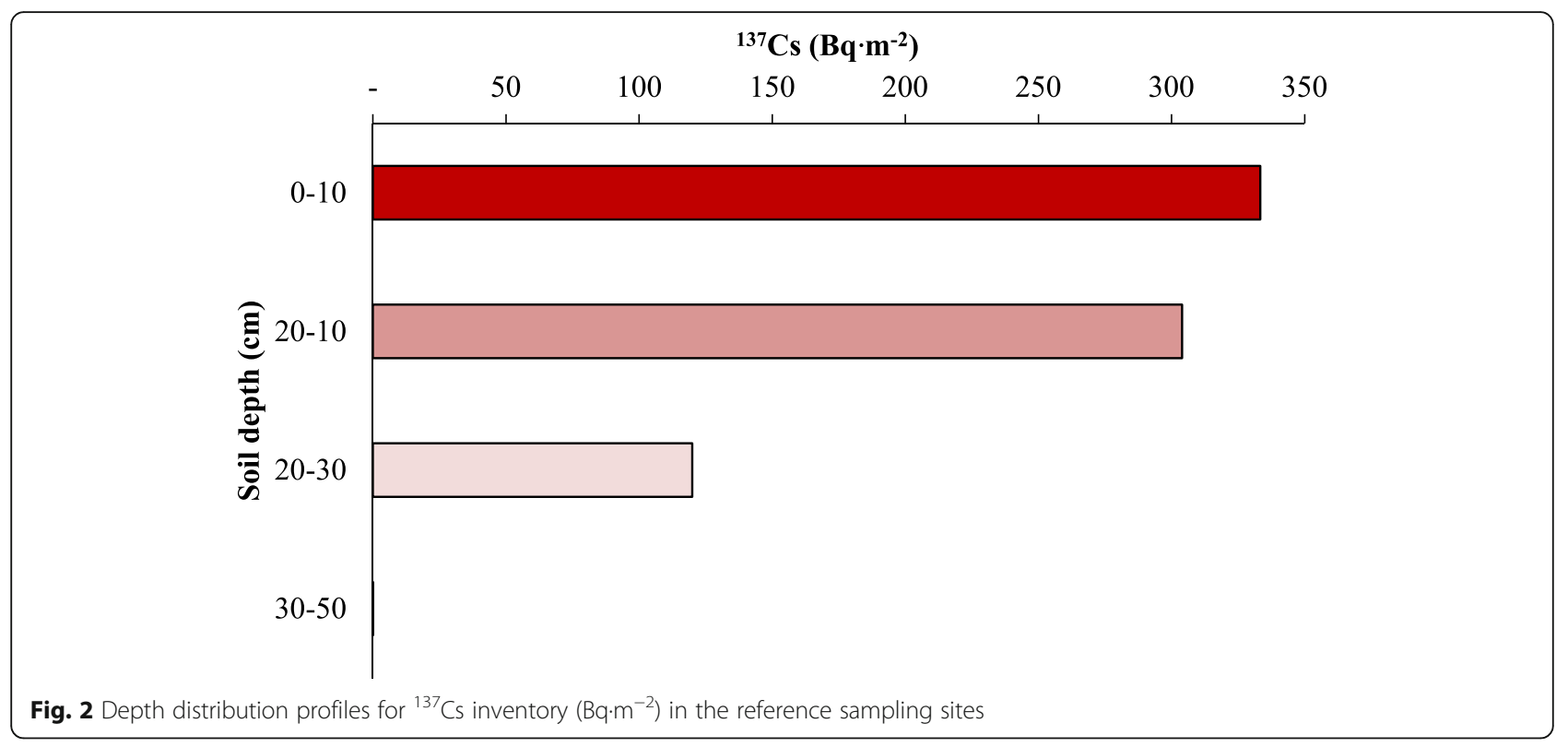

As demonstrated in Fig. 3, the ${ }^{137} \mathrm{Cs}$ values in the natural forest soils are significantly different between 0 and $10,10-20$, and $20-50 \mathrm{~cm}$ depths, but in the rainfed farming are significantly different between 0 and 10 and $10-20 \mathrm{~cm}$ depths in the summit positions (Fig. 3a and e). The natural forest soils showed considerably greater values of the ${ }^{137} \mathrm{Cs}$ than rainfed farming soils at three depths in summit position (Fig. 3a and e). The distribution of ${ }^{137} \mathrm{Cs}$ activity through the surface horizons was influenced by both plowing and soil erosion. There was a significant difference in ${ }^{137} \mathrm{Cs}$ activity distribution following the land-use change to rainfed farming in the upper $20 \mathrm{~cm}$ of the soil with subsoil in shoulder positions (Fig. 3f). The ${ }^{137} \mathrm{Cs}$ activity was showed a significant difference $(p<0.05)$ between 20 and 50 and $10-20$ $\mathrm{cm}$ depths in backslope and footslope positions in both land-uses (Fig. 3c and g). These findings indicate that the conversion of the natural forest land into rainfed farming significantly reduced ${ }^{137} \mathrm{Cs}$ values in each hillslope position.

The soil erosion estimation rate by SMBM was $(9.3$ $\left.\mathrm{t} \cdot \mathrm{ha}^{-1} \cdot \mathrm{yr}^{-1}\right)$ for the natural forest, while the higher soil loss $\left(51.1 \mathrm{t} \cdot \mathrm{ha}^{-1} \cdot \mathrm{yr}^{-1}\right)$ was calculated in rainfed farming. The sloping rainfed farming erosion rate is more than double that of the natural forest, suggesting that significant soil loss occurred during the agriculture practices after forest conversion (Fig. 4). By using SMBM in the Ardal district, west of Iran, Abbaszadeh et al. (2010) showed that soil erosion rates varied between 4.8 to $183.9 \mathrm{t} \cdot \mathrm{ha}^{-1} \cdot \mathrm{yr}^{-1}$ in rainfed farming.

The soil erosion and deposition rates were presented in Fig. 4 in oak forest and rainfed farming sites for four different hillslope positions. The highest soil erosion rate with a mean value of $162.3 \mathrm{t} \cdot \mathrm{ha}^{-1} \cdot \mathrm{yr}^{-1}$ occurred in the summit component of rainfed farming land-use. Previous studies showed that inclination is one of the most influential factors that could enhance soil loss in the highest hillslope position (i.e., summit position) (Bradford and Foster, 1966; Aksoy and Kavvas 2005; Assouline et al. 2006). The soil deposition occurred mainly in the back- and foot-slope positions in the natural forest area with mean values of 148.3 and $376 \mathrm{t}^{\mathrm{h}} \mathrm{ha}^{-1} \cdot \mathrm{yr}^{-1}$, respectively. This shows that eroded material from summit and shoulder positions are mobilized in the two lowest hillslope positions. In the rainfed farming areas, the highest soil erosion occurred on summit and shoulder positions with mean values of 162.3 and $99.3 \mathrm{t} \cdot \mathrm{ha}^{-1} \cdot \mathrm{yr}^{-1}$, respectively. Unlike the oak forest areas, soil erosion occurred on the backslope of the rainfed farming areas. In rainfed farming, the highest soil deposition rate occurred in the footslope position with a mean value of $140.95 \mathrm{t} \cdot \mathrm{ha}^{-1}$. $\mathrm{yr}^{-1}$. The sediments carried from the upslope parts deposited in the lower position (e.g., footslope position) (Fig. 4). Several studies obtained similar results (Sac et al. 2008; Abbaszadeh et al. 2010; Ayoubi et al. 2012b) confirmed the deposition rate in the downslopes (i.e., back- and foot-slope) was the highest.

The soil erosion rate in rainfed soils was greater than that of natural forest soils (Fig. 4). On the summit position, for instance, the soil erosion rate in all three rainfed farming land-use samples was $162.3 \mathrm{t} \cdot \mathrm{ha}^{-1} \cdot \mathrm{yr}^{-1}$, but in the oak forest was only $7.2 \mathrm{t} \cdot \mathrm{ha}^{-1} \cdot \mathrm{yr}^{-1}$. The soil erosion rate on the shoulder position of rainfed farming land-use $\left(99.3 \mathrm{t} \cdot \mathrm{ha}^{-1} \cdot \mathrm{yr}^{-1}\right)$ was much higher than natural forest land-use (32.4 t.ha $\left.{ }^{-1} \cdot \mathrm{yr}^{-1}\right)$ (Fig. 4). The soil losses in the summit and shoulder positions obtained by the SMBM showed significant differences $(p<0.05)$ for the oak forest and the rainfed farming. Also, there was a 

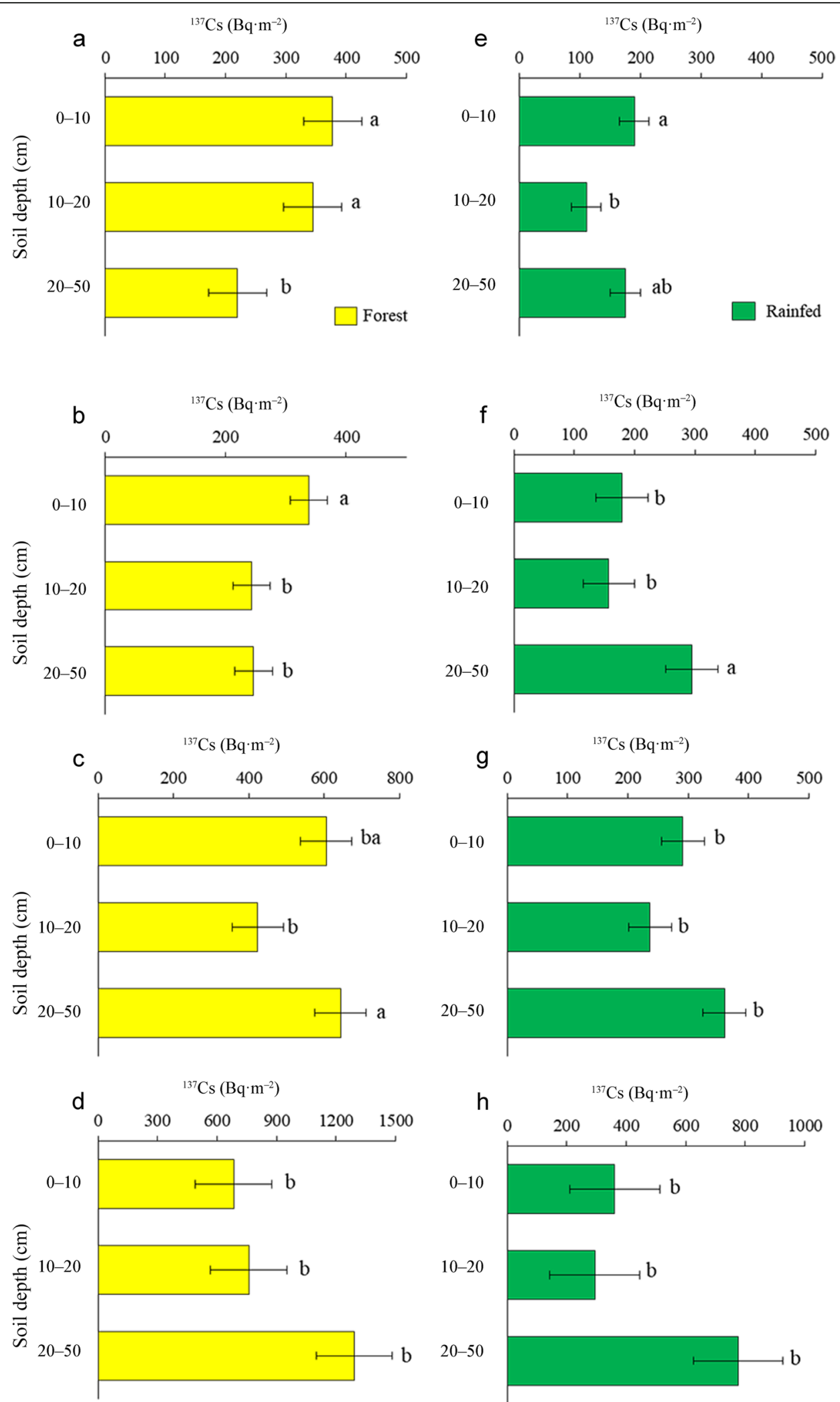

Fig. 3 Depth distribution profiles for ${ }^{137} \mathrm{Cs}$ inventory $\left(\mathrm{Bq} \cdot \mathrm{m}^{-2}\right)$ in forest land-use $(\mathbf{a})$, summit $(\mathbf{b})$, shoulder $(\mathbf{c})$, backslope (d) footslope and rainfed land-use $(\mathbf{e})$, summit $(\mathbf{f})$,shoulder $(\mathbf{g})$, backslope $(\mathbf{h})$ footslope. Different letters on the bars show the statistical difference at $p<0.05$ 


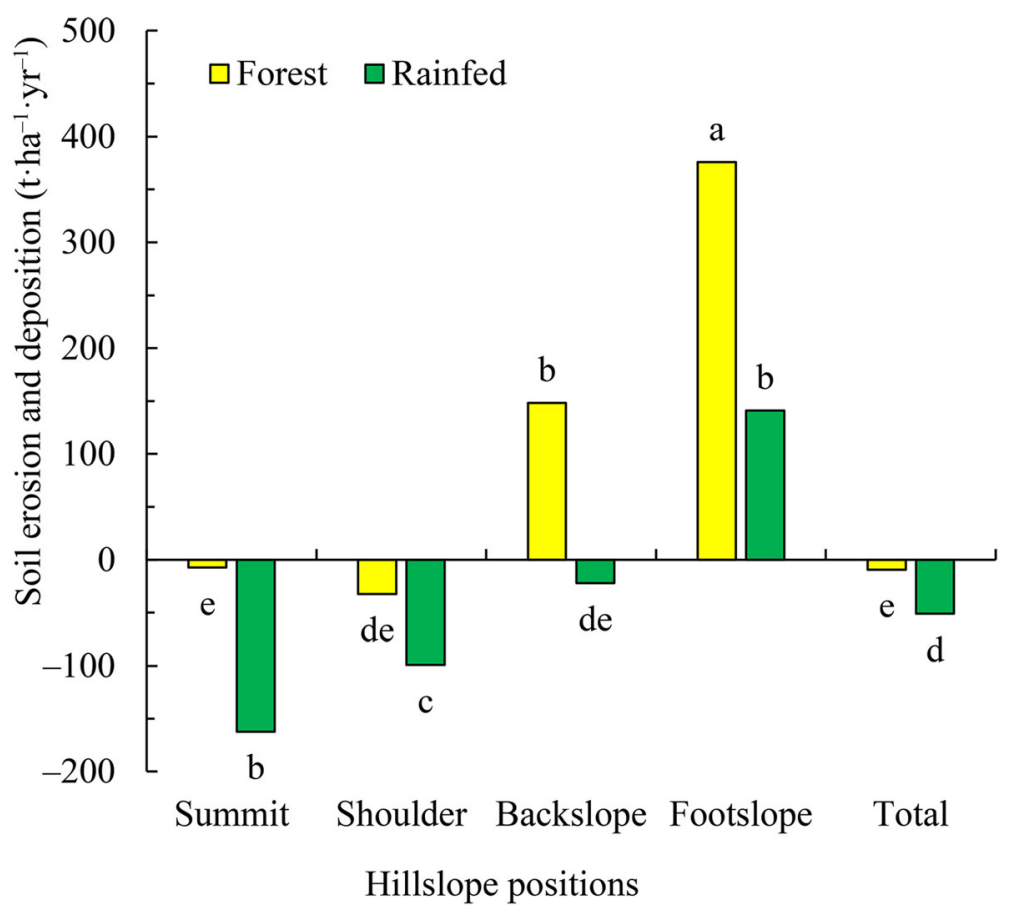

Fig. 4 The soil erosion rates and deposition in natural forest and rainfed farming per hillslope positions (summit, shoulder, backslope, and footslope). Different letters on the bars show the statistical difference at $p<0.05$

significant difference $(p<0.05)$ between the two landuses for the backslope and footslope positions according to soil deposition (Fig. 4). Higher soil redistribution on different hillslope positions of rainfed farming lands compared with forest land-use confirmed changing landuse (e.g., human activity), which remarkably enhances soil erosion in the study area. Moreover, the tillage practices and loss of vegetation cover in the steep slopes of the cultivated areas were considered as the major factors affecting soil properties in the studied area. Therefore, removing vegetation cover or tillage practices could increase the probability of large erosion events. Sheet and rill erosion are the dominant erosion processes within the rainfed cultivation catchment. These findings are in line with the findings of Mokhtari Karchegani et al. (2011) and Ayoubi et al. (2012a). Although rainfed farming vegetation could help to sustain the soil, but the vegetation cover would be less dense and stable than after deforestation. Additionally, the tree roots improved soil water retention and reduced the direct effect of rainfall splash (Wittenberg et al. 2020).

Soil property variations in slope positions and land-uses In the oak forest soil, the mean MS at high frequency $\left(\chi_{\mathrm{hf}}\right)$ was significantly $(p<0.05)$ higher than in the rainfed agricultural soil (Fig. 5a). The undisturbed soil with a lower soil loss in the summit and shoulder positions of hillslope (Fig. 4) indicated higher $\chi_{\mathrm{hf}}$ rather than in the disturbed soils (Fig. 5). On the other hand, due to soil deposition in the backslope and footslope positions, $\chi_{\mathrm{hf}}$ showed higher value than other positions. Furthermore, in the downslope positions, especially in the natural forest land, the pedogenic process was more intense because of the water received from the upslope in the form of surface and sub-surface flows, which can cause the leaching of carbonates and enhanced $\chi_{\mathrm{hf}}$ (Singer et al. 1996; Ayoubi et al. 2012a; Rahimi et al. 2013). There was no significant difference in $\chi_{\mathrm{hf}}$ in rainfed farming soils, which could be related to soil tillage disturbance (Fig. 5a). These findings agree with Liu et al. (2018), who stated a significant positive correlation between soil erosion and magnetic properties. The location of the hillslope position influences the variability of soil attributes, especially magnetic properties. There is evidence within the hillslope for soil movement as soil erosion occurs in the shoulder and backslope and soil deposition in downslope positions.

SOM in the natural oak forest soil was significantly $(p<0.05)$ higher than in the rainfed farming soil. The lowest SOM was observed in both land-uses in the shoulder position, which was associated with the highest slope and soil loss rate. In addition, SOM was significantly $(p<0.05)$ in both land-uses in different hillslope positions (Fig. 5b). On the other hand, Ayoubi et al. (2012a) and Nosrati et al. (2015) obtained the low SOM in shoulder positions of hillslope in the Chelgerd Nachi 


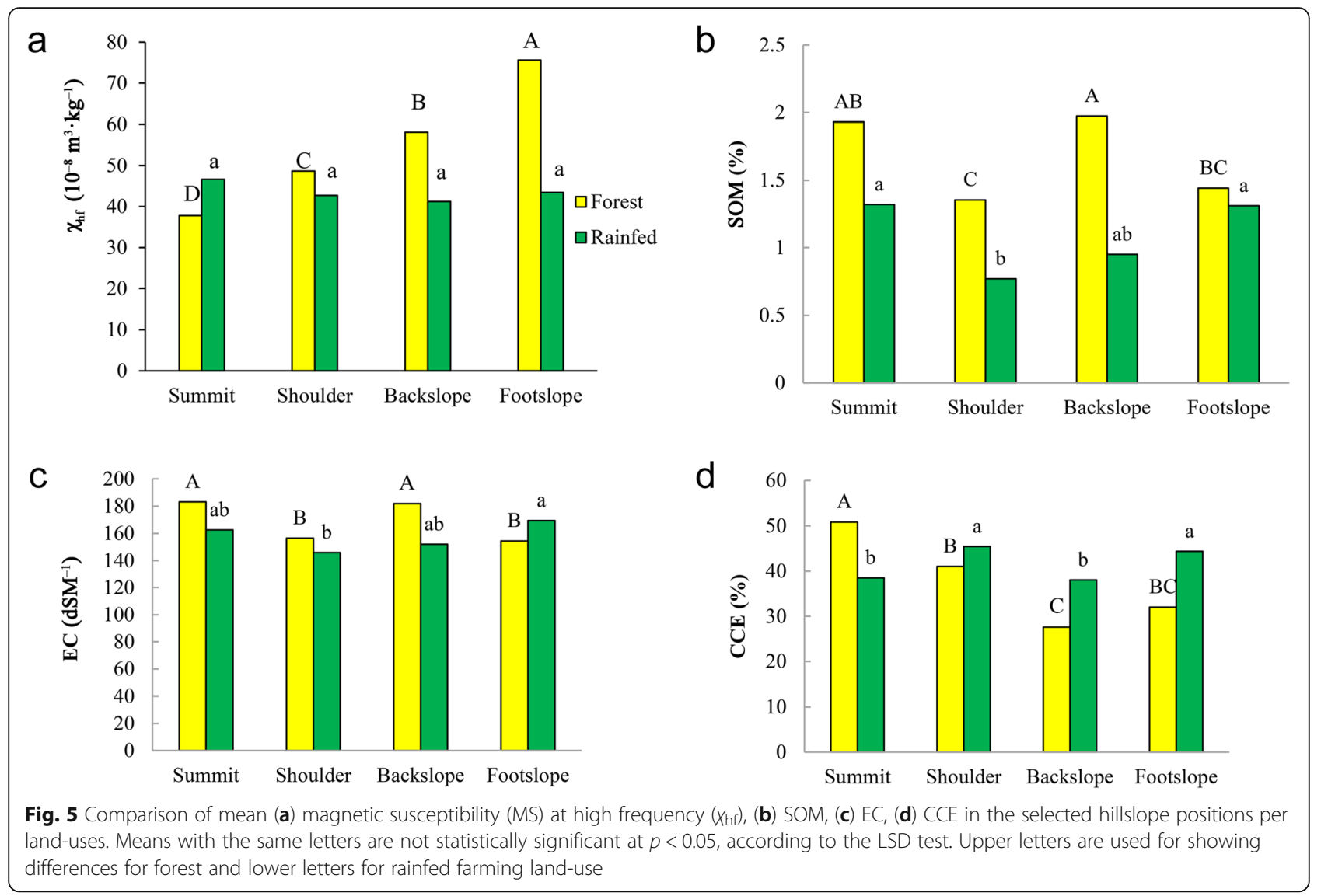

District in the west of Iran. This may be contributed by higher soil temperature because of low vegetation cover, less shading, and subsequent susceptibility of soils to erosion (Pathak et al. 2005; Sugasti and Pinzón 2020).

The lowest EC has been observed in the shoulder and footslope positions in rainfed and oak forest land-uses. There was a significant difference $(p<0.05)$ between the shoulder and footslope positions in rainfed farming land-use for EC. There was a significant difference in EC in natural forest soils between the summit, backslope, and shoulder, footslope positions. The findings indicated that hillslope components and land-uses independently affect soil properties and change their values in different hillslope components and land-uses (Fig. 5c).

Calcium carbonate equivalent (CCE) in the rainfed farming soil in all of the hillslope positions except in the summit was significantly $(p<0.05)$ higher than in the natural forest soil. There were significant differences $(p<0.05)$ between summit and backslope with shoulder and footslope positions in CCE in rainfed farming soils, which could be related to the soil's heterogeneity due to plowing and different stability of hillslope positions (Khormali et al. 2006). In natural forest soils, there were significant differences $(p<0.05)$ in CCE contents in different hillslope positions. The highest and lowest CCE values were observed in the summit and backslope positions in oak forest land-use (Fig. 5d). Moreover, in rainfed farming, the low and high CCE values in the summit and footslope positions could be due to soil erosion in the upper hillslope position (i.e., summit) and deposition in the lower hillslope position (i.e., footslope) (Fig. 5d). A previous study showed that CCE variations could be used to indicate soil loss and landscape stability (Khormali et al. 2006). A variety of complex processes accounting for the CCE dynamics in the soil (Khormali et al. 2006; Khormali et al. 2009).

\section{Potential carbon sequestration in soil}

To estimate the additional amount of carbon, which could be sequestered as complexed $\mathrm{OC}$ in each land-use, complexed and non-complexed carbon and clay were calculated using Eqs. 1-4. Afterward, the potential additional complexed OC was calculated. The mean clay content varied between 1 to $57 \mathrm{~g} \cdot 100 \mathrm{~g}^{-1}$ at a depth of $0-30 \mathrm{~cm}$, and no significant differences were observed between the land-uses. By using $n=$ clay/(SOC concentration $)=10$, the average complexed clay $(\mathrm{CC})$ in the oak forest and rainfed farmlands was found to be 20.8 and $21.8 \mathrm{~g} \cdot 100 \mathrm{~g}^{-1}$, respectively. As shown in Fig. 6, the saturation line is the boundary for controlling non- 


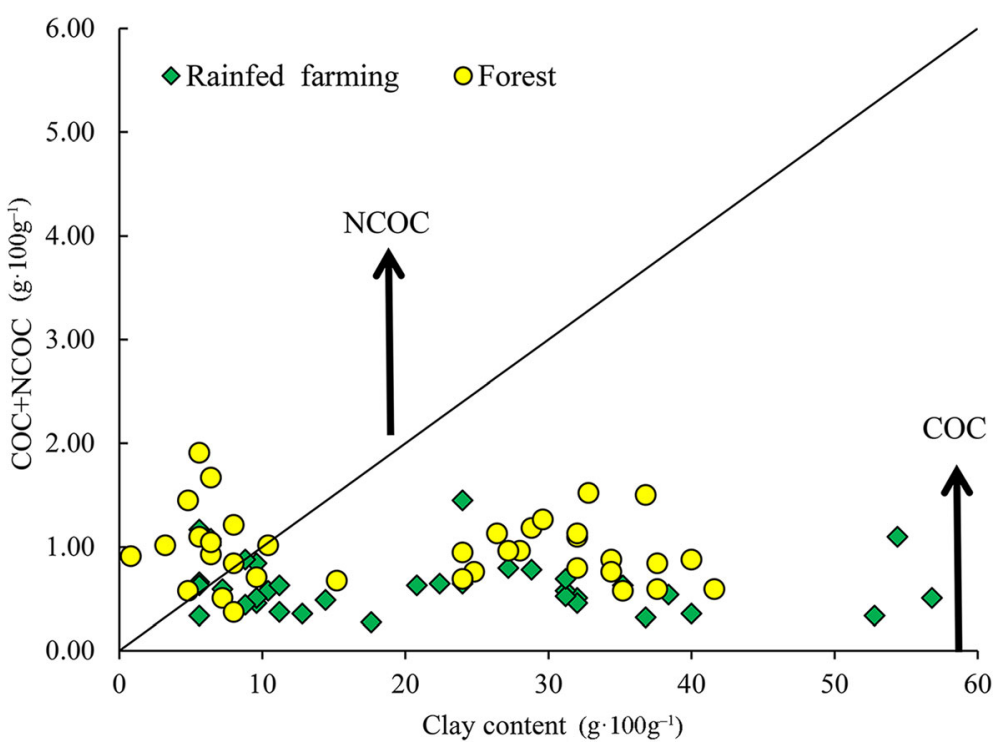

Fig. 6 Application of Dexter's clay to carbon saturation concept per land-uses. The line corresponds to the saturation trend (1:10)

complexed organic carbon (NCOC) and non-complexed clay (NCC). More the soils were located under the saturation line (Fig. 6), the amount of complexed clay (CC) corresponded to the complexed organic carbon (COC) (whole amount of SOC concentration), and the noncomplexed organic carbon (NCOC) was equal to 0 . The texture of the oak forest soil is closer to the saturation line. In the natural forest, soil behavior is affected by non-complexed carbon. However, in rainfed farming, due to the heavy texture of the soil, the composition of the soil is affected by non-complexed clay. This indicates that the textures of the two land-uses are not the same. Alidoust et al. (2018) assess and compare improvements and capacity of SOC sequestration under various landuses in western central Iran. The findings revealed that all soils analyzed consisted of non-complexed clay, showing a significant carbon sequestration capacity. Moreover, the findings have shown that the SOC controlling variables differed considerably between landuses and soil depths. Reduction of inputs biomass, acceleration of soil erosion, and the increase of SOM turnover rate are the key factors for the SOC concentration reduction due to the conversion of forest to agricultural lands (Albaladejo et al. 2013). Some studies have also shown that the depletion of SOC land-use conversion to agricultural lands in the semi-arid areas could be higher than in humid areas (Martinez-Mena et al. 2008).

\section{Conclusions}

Soil redistribution rate demonstrates remarkably higher erosion in rainfed farming than natural forest (oak forest) soils. The results of using ${ }^{137} \mathrm{Cs}$ radionuclide measurements indicated severe erosion in the summit $\left(162.3 \mathrm{t} \cdot \mathrm{ha}^{-1} \cdot \mathrm{yr}^{-1}\right)$ and shoulder $\left(99.3 \mathrm{t} \cdot \mathrm{ha}^{-1} \cdot \mathrm{yr}^{-1}\right)$ hillslope positions of rainfed farming soil after changes from oak forests. This confirms that land-use changes from the undisturbed ecosystem (i.e., natural forest) to disturbed ecosystems (i.e., dryland farming) significantly increase soil erosion. The shoulder and summit positions were the most erodible hillslope positions in the natural forest and rainfed farming, respectively. These results highlight the critical role of hillslope position and landuse changes in eroding the surface soils in hilly natural and anthropogenic areas. In addition, the results illustrated that land management has a powerful influence on soil erosion intensity and may both mitigate and amplify soil loss. Our findings present evidence that the combined influence of soil redistribution and land-use change applies a significant control over the spatial distribution of soil properties. Therefore, the data obtained achieves a better understanding of the effect of land-use change and land management in the Zagros region.

\footnotetext{
Abbreviations

${ }^{137}$ Cs: Caesium-137; MS: Magnetic susceptibility; Xhf: MS at high frequency; $X_{\text {ff: }}$ MS at low frequency; $X_{f d}$ : Dependent frequency MS; SOM: Soil organic matter; TN: Total nitrogen; EC: Electrical conductivity; $K_{\text {ava: }}$ Extractable potassium; $P_{\text {ava: }}$ Extractable phosphorous; CCE: Calcium carbonate equivalent; SMBM: Simplified Mass Balance Model; OC: Organic carbon; CC: Complexed clays; NCC: Non-complexed clays; COC: Complexed organic carbons; NCOC: Non-complexed organic carbons; PAOC: Potential additional complexed organic carbon; CMAX: Maximum possible amount of complexed OC; CV: Coefficient of variation; Min: Minimum; Max: Maximum; pH: Soil acidity; BD: Bulk density
}

Acknowledgments

The authors thank the Isfahan University of Technology for providing the experimental facilities. Mojtaba Zeraatpisheh's postdoctoral program at Henan University, China, has been supported by the National Key Research 
and Development Program of China, grant numbers 2017YFA0604302 and 2018 YFA0606500.

\section{Authors' contributions}

SA: Conceptualization, Methodology, Software, Validation, Writing - original draft, Writing - review \& editing, Visualization, Supervision; NS: Methodology, Software, Validation, Writing - original draft, Writing - review \& editing, Visualization; FAA: Writing - original draft and Writing - review \& editing; MRA: Methodology and Writing - review \& editing; MZ: Writing - original draft, Writing - review \& editing, Supervision, and Visualization; JR: Writing review \& editing. The authors read and approved the final manuscript.

\section{Funding}

There is no external funding for this work.

\section{Declarations}

\section{Ethics approval and consent to participate}

Not applicable.

\section{Consent for publication}

Not applicable.

\section{Competing interests}

The authors declare they have no competing interests.

\section{Author details}

${ }^{1}$ Department of Soil Science, College of Agriculture, Isfahan University of Technology, Isfahan 84156-83111, Iran. ${ }^{2}$ Department of Soil Science, College of Agriculture, University of Jiroft, Kerman, Iran. ${ }^{3}$ Department of Physics, Faculty of Science, University of Isfahan, Isfahan 81747-73441, Iran. ${ }^{4}$ Henan Key Laboratory of Earth System Observation and Modeling, Henan University, Kaifeng 475004, China. ${ }^{5}$ College of Environment and Planning, Henan University, Kaifeng 475004, China. ${ }^{6}$ Department of Physical Geography, University of Trier, Trier, Germany. ${ }^{7}$ Soil Erosion and Degradation Research Group, Department of Geography, Universitat de València, Valencia, Spain.

Received: 11 January 2021 Accepted: 10 May 2021

Published online: 24 May 2021

\section{References}

Abbaszadeh F, Ayoubi S, Jalalian A (2010) Soil redistribution rate and its relationship with soil organic carbon and total nitrogen using ${ }^{137} \mathrm{CS}$ technique in a cultivated complex hillslope in western Iran. J Environ Radioact 101(8):606-614

Ajami M, Heidari A, Khormali F, Zeraatpisheh M, Gorji M, Ayoubi S (2020) Spatial variability of rainfed wheat production under the influence of topography and soil properties in loess-derived soils, northern Iran. Int J Plant Prod 14(4): 597-608. https://doi.org/10.1007/s42106-020-00106-4

Aksoy H, Kavvas ML (2005) A review of hillslope and watershed scale erosion and sediment transport models. Catena 64(2-3):247-271. https://doi.org/10.1016/j. catena.2005.08.008

Akter T, Quevauviller P, Eisenreich SJ, Vaes G (2018) Impacts of climate and land use changes on flood risk management for the Schijn River, Belgium. Environ Sci Pol 89:163-175. https://doi.org/10.1016/j.envsci.2018.07.002

Al Sayah MJ, Abdallah C, Khouri M, Nedjai R, Darwich T (2019) Application of the LDN concept for quantification of the impact of land use and land cover changes on Mediterranean watersheds - Al Awali basin - Lebanon as a case study. Catena 176:264-278. https://doi.org/10.1016/j.catena.2019.01.023

Albaladejo J, Ortiz R, Garcia-Franco N, Navarro AR, Almagro M, Pintado JG, Martínez-Mena M (2013) Land use and climate change impacts on soil organic carbon stocks in semi-arid Spain. J Soils Sediments 13(2):265-277. https://doi.org/10.1007/s11368-012-0617-7

Alidoust E, Afyuni M, Hajabbasi MA, Mosaddeghi MR (2018) Soil carbon sequestration potential as affected by soil physical and climatic factors under different land uses in a semi-arid region. Catena 171:62-71. https://doi.org/1 0.1016/j.catena.2018.07.005

Assouline S, Ben-Hur M (2006) Effects of rainfall intensity and slope gradient on the dynamics of interrill erosion during soil surface sealing. Catena 66(3):211220. https://doi.org/10.1016/j.catena.2006.02.005
Ayoubi S, Ahmadi M, Abdi MR, Abbaszadeh Afshar F (2012a) Relationships of ${ }^{137} \mathrm{Cs}$ inventory with magnetic measures of calcareous soils of hilly region in Iran. J Environ Radioact 112:45-51. https://doi.org/10.1016/j.jenvrad.2012.03. 012

Ayoubi S, Mokhtari J, Mosaddeghi MR, Zeraatpisheh M (2018) Erodibility of calcareous soils as influenced by land use and intrinsic soil properties in a semi-arid region of Central Iran. Environ Monit Assess 190(4):192. https://doi. org/10.1007/s10661-018-6557-y

Ayoubi S, Mokhtari Karchegani P, Mosaddeghi MR, Honarjoo N (2012b) Soil aggregation and organic carbon as affected by topography and land use change in western Iran. Soil Till Res 121:18-26. https://doi.org/10.1016/j.still.2 012.01.011

Bajocco S, De Angelis A, Perini L, Ferrara A, Salvati L (2012) The impact of land use/land cover changes on land degradation dynamics: a Mediterranean case study. Environ Manag 49(5):980-989. https://doi.org/10.1007/s00267012-9831-8

Bakhshandeh E, Hossieni M, Zeraatpisheh M, Francaviglia R (2019) Land use change effects on soil quality and biological fertility: a case study in northern Iran. Eur J Soil Biol 95:103119. https://doi.org/10.1016/j.ejsobi.2019.103119

Bazshoushtari N, Ayoubi S, Abdi MR (2016) Variability of ${ }^{137} \mathrm{Cs}$ inventory at a reference site in west-Central Iran. J Environ Radioact 165:86-92. https://doi. org/10.1016/j.jenvrad.2016.09.010

Black CA, Evans DD, White JL, Ensminger LE, Clark FE (1965) Methods of soil analysis, part 2. Agronomy monograph no. 9. ASA and soil science Society of America, Madison

Blake GR, Hartge KH (1986) Bulk density. In: Klute A (ed) Methods of soil analysis. Part l: physical and mineralogical methods, second agronomy monograph no 9. American Society of Agronomy, Madison, pp 363-375

Bradford JM, Foster GR (1966) Interril soil erosion and slope steepness factors. Soi Sci Soc Am J 60:909-915

Bremmer JM, Mulvaney CS (1982) Total nitrogen. In: Page AL, Miller RH, Keeney DR (eds) Methods of soil analysis, part 2: chemical and microbiological properties, 2nd edn. Agronomy monograph no. 9. American Society of Agronomy, Madison

Celik I (2005) Land-use effects on organic matter and physical properties of soil in a southern Mediterranean highland of Turkey. Soil Till Res 83(2):270-277. https://doi.org/10.1016/j.still.2004.08.001

Cerdà A, Rodrigo-Comino J (2020) Is the hillslope position relevant for runoff and soil loss activation under high rainfall conditions in vineyards? Ecohydrol Hydrobiol 20(1):59-72. https://doi.org/10.1016/j.ecohyd.2019.05.006

Chaharmahal and Bakhtiari Meteorological Administration (2019) http://www. chbmet.ir/en/dataarchive.asp. Accessed 15 Jan 2021

Chauchard S, Carcaillet C, Guibal F (2007) Patterns of land-use abandonment control tree-recruitment and forest dynamics in Mediterranean mountains. Ecosystems 10(6):936-948. https://doi.org/10.1007/s10021-007-9065-4

Curtis PG, Slay CM, Harris NL, Tyukavina A, Hansen MC (2018) Classifying drivers of global forest loss. Science 361(6407):1108-1111. https://doi.org/10.1126/ science.aau3445

de Neergaard A, Magid J, Mertz O (2008) Soil erosion from shifting cultivation and other smallholder land use in Sarawak, Malaysia. Agric Ecosyst Environ 125(1-4):182-190. https://doi.org/10.1016/j.agee.2007.12.013

Dexter AR, Richard G, Arrouays D, Czyz EA, Jolivet C, Duval O (2008) Complexed organicmatter controlssoil physical properties. Geoderma 144(3-4):620-627. https://doi.org/10.1016/j.geoderma.2008.01.022

Ehrenberg R (2015) Global count reaches 3 trillion trees. Nature. https://doi.org/1 0.1038 /nature.2015.18287

Elliott GL, Campbell BL, Loughran RJ (1990) Correlation of erosion measurements and soil caesium-137 content. Appl Radiat Isotopes 41(8):713-717. https:// doi.org/10.1016/0883-2889(90)90017-B

Foley JA, DeFries R, Asner GP, Barford C, Bonan G, Carpenter SR, Chapin FS, Coe MT, Daily GC, Gibbs HK, Helkowski JH, Holloway T, Howard EA, Kucharik CJ, Monfreda C, Patz JA, Prentice IC, Ramankutty N, Snyder PK (2005) Global consequences of land use. Science 309(5734):570-574. https://doi.org/10.112 6/science.1111772

Forest (2018) Range and Watershed Management Organication (FRWO). https:// www.frw.ir/02/en/staticpages/page.aspx?tid=13231. Accessed 15 Jan 2021

Fu B-J, Wang Y-F, Lu Y-H, He C-S, Chen L-D, Song C-J (2009) The effects of landuse combinations on soil erosion: a case study in the loess plateau of China. Prog Phys Geogr 33(6):793-804. https://doi.org/10.1177/030913330935026

Gee GW, Bauder JW (1986) Particle size analysis. In: Klute A (ed) Methods of soil analysis, part 1. Am Soc Agron, Elsevier Science, Amsterdam, pp 383-411 
Hill J, Stellmes M, Udelhoven T, Röder A, Sommer S (2008) Mediterranean desertification and land degradation: mapping related land use change syndromes based on satellite observations. Glob Planet Chang 64(3-4):146157. https://doi.org/10.1016/j.gloplacha.2008.10.005

Houghton RA, House Jl, Pongratz J, Van Der Werf GR, DeFries RS, Hansen MC, Quéré CL, Ramankutty N (2012) Carbon emissions from land use and landcover change. Biogeosciences 9(12):5125-5142. https://doi.org/10.5194/bg-95125-2012

Hu Y, Zhang Y (2019) Using ${ }^{137} \mathrm{Cs}$ and ${ }^{210} \mathrm{~Pb}_{\text {ex }}$ to investigate the soil erosion and accumulation moduli on the southern margin of the Hunshandake Sandy land in Inner Mongolia. J Geogr Sci 29(10):1655-1669. https://doi.org/10.1 007/s11442-019-1983-1

Jones RJA, Verheijen FGA, Reuter HI, Jones AR. (eds). Environmental Assessment of Soil for Monitoring Volume V: Procedures \& Protocols. EUR 23490 EN/5, Office for the Official Publications of the European Communities, Luxembourg; 2008. 165 pp.

Jordan G, Van Rompaey AJ, Szilassi P, Csillag G, Mannaerts C, Woldai T (2005) Historical land use changes and their impact on sediment fluxes in the Balaton basin (Hungary). Agric Ecosyst Environ 108(2):119-133. https://doi. org/10.1016/j.agee.2005.01.013

Kavian A, Sabet SH, Solaimani K, Jafari B (2017) Simulating the effects of land use changes on soil erosion using RUSLE model. Geocarto Int 32(1):97-111. https://doi.org/10.1080/10106049.2015.1130083

Kelishadi H, Mosaddeghi MR, Hajabbasi MA, Ayoubi S (2014) Near-saturated soil hydraulic properties as influenced by land use management systems in Koohrang region of central Zagros, Iran. Geoderma 213:426-434. https://doi. org/10.1016/j.geoderma.2013.08.008

Khormali F, Abtahi A, Stoops G (2006) Micromorphology of calcitic features in highly calcareous soils of Fars Province, southern Iran. Geoderma 132(1-2): 31-46. https://doi.org/10.1016/j.geoderma.2005.04.024

Khormali F, Ajami M, Ayoubi S, Srinivasarao C, Wani S (2009) Role of deforestation and hillslope position on soil quality attributes of loess-derived soils in Golestan province, Iran. Agric Ecosyst Environ 134(3-4):178-189. https://doi. org/10.1016/j.agee.2009.06.017

Kosmas C, Moustakas N, Danalatos NG, Yassoglou N (1995) The effect of land use change on soil properties and erosion along a catena. In: Thornes JB, Brandt CJ (eds) Mediterranean desertification and land use. Wiley, Chichester, pp 207-227

Lal R (2015) Restoring soil quality to mitigate soil degradation. Sustainability 7(5): 5875-5895. https://doi.org/10.3390/su7055875

Li X-G, Li F-M, Zed R, Zhan Z-Y (2007) Soil physical properties and their relations to organic carbon pools as affected by land use in an alpine pastureland. Geoderma 139(1-2):98-105. https://doi.org/10.1016/j. geoderma.2007.01.006

Li Z, Liu C, Dong Y, Chang X, Nie X, Liu L, Xiao H, Lu Y, Zeng G (2017) Response of soil organic carbon and nitrogen stocks to soil erosion and land use types in the loess hilly-gully region of China. Soil Till Res 166:1-9. https://doi.org/1 0.1016/j.still.2016.10.004

Liu D, Huang Y, An S, Sun H, Bhople P, Chen Z (2018) Soil physicochemical and microbial characteristics of contrasting land-use types along soil depth gradients. Catena 162:345-353. https://doi.org/10.1016/j.catena.2017.10.028

MacDonald D, Crabtree JR, Wiesinger G, Dax T, Stamou N, Fleury P, Gutierrez Lazpita J, Gibon A (2000) Agricultural abandonment in mountain areas of Europe: environmental consequences and policy response. J Environ Manag 59(1):47-69. https://doi.org/10.1006/jema.1999.0335

Martinez-Mena M, Lopez J, Almagro M, Boix-Fayos C, Albaladejo J (2008) Effect of water erosion and cultivation on the soil carbon stock in a semiarid area of southEast Spain. Soil Tillage Res 99(1):119-129. https://doi.org/10.1016/j.still.2008.01.009

Meliho M, Nouira A, Benmansour M, Boulmane M, Khattabi A, Mhammdi N, Benkdad A (2019) Assessment of soil erosion rates in a Mediterranean cultivated and uncultivated soils using fallout ${ }^{137} \mathrm{Cs}$. J Environ Radioact 208209:106021

Mojiri A, Aziz HA, Ramaji A (2012) Potential decline in soil quality attributes as a result of land use change in a hillslope in Lordegan, western Iran. Afr J Agr Res 7(4):577-582. https://doi.org/10.5897/AJAR11.1505

Mokhtari Karchegani P, Ayoubi S, Lu S, Honarju N (2011) Use of magnetic measures to assess soil redistribution following deforestation in hilly region. J Appl Geophys 75(2):227-236. https://doi.org/10.1016/j.jappgeo.2011.07.017

Nabiollahi K, Heshmat E, Mosavi A, Kerry R, Zeraatpisheh M, Taghizadeh-Mehrjardi $R$ (2020) Assessing the influence of soil quality on rainfed wheat yield. Agriculture 10(10):469. https://doi.org/10.3390/agriculture10100469
Naghipour AA, Bashari H, Khajeddin SJ, Tahmasebi P, Iravani M (2016) Effects of smoke, ash and heat shock on seed germination of seven species from central Zagros rangelands in the semi-arid region of Iran. Afr J Range Forest Sci 33(1):67-71. https://doi.org/10.2989/10220119.2015.1119194

Nelson DW, Sommers LE (1996) Total carbon, organic carbon, and organic matter. In: Bartels JM, Bigham JM (eds) Methods of soil analysis: part 3 chemical methods. American Society of Agronomy, Madison, pp 961-1010

Nosrati K, Haddadchi A, Zare MR, Shirzadi L (2015) An evaluation of the role of hillslope components and land use in soil erosion using ${ }^{137} \mathrm{Cs}$ inventory and soil organic carbon stock. Geoderma 243-244:29-40

Novara A, Cerdà A, Dazzi C, Lo Papa G, Santoro A, Gristina L (2015) Effectiveness of carbon isotopic signature for estimating soil erosion and deposition rates in Sicilian vineyards. Soil Till Res 152:1-7. https://doi.org/10.1016/j.still.2015.03. 010

Olson KR, Gennadiyev AN, Zhidkin AP, Markelov MV, Golosov VN, Lang JM (2013) Use of magnetic tracer and radio-cesium methods to determine past cropland soil erosion amounts and rates. Catena 104:103-110. https://doi. org/10.1016/j.catena.2012.10.015

Orgiazzi A, Ballabio C, Panagos P, Jones A, Fernándezes-Ugalde O (2018) LUCAS soil, the largest expandable soil dataset for Europe: a review. Eur J Soil Sci 69(1):140-153. https://doi.org/10.1111/ejss.12499

Pathak P, Sahrawat KL, Rego TJ, Wani SP (2005) Measurable biophysical indicators for impact assessment: changes in soil quality. In: Shiferaw B, Freeman HA, Swinton SM (eds) Natural resource management in agriculture: methods for assessing economical and environmental impacts. ICRISAT, Patancheru. https://doi.org/10.1079/9780851998282.0053

Quesada B, Arneth A, Robertson E, de Noblet-Ducoudré N (2018) Potential strong contribution of future anthropogenic land-use and land-cover change to the terrestrial carbon cycle. Environ Res Lett 13(6):064023. https://doi.org/10.1 088/1748-9326/aac4c3

Rahimi MR, Ayoubi S, Abdi MR (2013) Magnetic susceptibility and Cs-137 inventory variability as influenced by land use change and slope positions in a hilly semi-arid region of west-Central Iran. J Appl Geophys 89:68-75. https://doi.org/10.1016/j.jappgeo.2012.11.009

Rhoades JD (1982) Soluble salts. In: Page AL. Methods of soil analysis, part 3, 2nd edn. Agronomy monograph, no. 9. American Society of Agronomy, Madison, 167

Richards LA (1954) Diagnosis and improvement of saline and alkaline soil. USDA hand book Office, Washington DC

Ritchie JC, Ritchie CA (2007) Bibliography of publications of 137-cesium studies related to erosion and sediment deposition. http://www.ars.usda.gov/Main/ docs.htm?docid1/415237. Accessed 15 Jan 2021

Rodrigo-Comino J, Keesstra S, Cerdà A (2018) Soil erosion as an environmental concern in vineyards: the case study of Celler del Roure, eastern Spain, by means of rainfall simulation experiments. Beverages 4(2):31. https://doi.org/1 0.3390/beverages4020031

Rodrigo-Comino J, López-Vicente M, Kumar V, Rodríguez-Seijo A, Valkó O, Rojas C, Pourghasemi HR, Salvati L, Bakr N, Vaudour E, Brevik EC, Radziemska M, Pulido M, Prima SD, Dondini M, de Vries W, Santos ES, de Lourdes Mendonça-Santos M, Yu Y, Panagos P (2020a) Soil science challenges in a new era: a transdisciplinary overview of relevant topics. Air Soil Water Res 13: 117862212097749. https://doi.org/10.1177/1178622120977491

Rodrigo-Comino J, Ruiz Sinoga JD, Senciales González JM, Guerra-Merchán A, Seeger M, Ries JB (2016) High variability of soil erosion and hydrological processes in Mediterranean hillslope vineyards (Montes de Málaga, Spain). Catena 145:274-284. https://doi.org/10.1016/j.catena.2016.06.012

Rodrigo-Comino J, Senciales JM, Ramos MC, Martínez-Casasnovas JA, Lasanta T, Brevik EC, Ries JB, Ruiz Sinoga JD (2017) Understanding soil erosion processes in Mediterranean sloping vineyards (Montes de Málaga, Spain). Geoderma 296:47-59. https://doi.org/10.1016/j.geoderma.2017.02.021

Rodrigo-Comino J, Terol E, Mora G, Gimenez-Morera A, Cerdà A (2020b) Vicia sativa Roth. Can reduce soil and water losses in recently planted vineyards (Vitis vinifera L.). Earth Syst Environ 4(4):827-842. https://doi.org/10.1007/s41 748-020-00191-5

Sac MM, Ugur A, Yener G, Ozden B. Estimates of soil erosion using cesium-137 tracer models. Environ Monitor Assess. 2008;136:461e467.

Saedi T, Shorafa M, Gorji M, Khalili Moghadam B (2016) Indirect and direct effects of soil properties on soil splash erosion rate in calcareous soils of the central zagross, Iran: a laboratory study. Geoderma 271:1-9. https://doi.org/10.1016/j. geoderma.2016.02.008

Singer MJ, Verousb KL, Fine P, TemPas J (1996) A conceptual model for the enhancement of magnetic susceptibility in soils. Quatern Int 34-36:243-248 
Soil Survey Staff (2010) Keys to soil taxonomy, 11th edn. United States Department of Agriculture, Natural Resources Conservation Services, Washington DC

Sugasti L, Pinzón R (2020) First approach of abiotic drivers of soil $\mathrm{CO}_{2}$ efflux in Barro Colorado Island, Panama. Air Soil Water Res 13:117862212096009. https://doi.org/10.1177/1178622120960096

Szilassi P, Jordan G, van Rompaey A, Csillag G (2006) Impacts of historical land use changes on erosion and agricultural soil properties in the Kali Basin at Lake Balaton, Hungary. Catena 68(2-3):96-108. https://doi.org/10.1016/j.ca tena.2006.03.010

Taghizadeh-Mehrjardi R, Bawa A, Kumar S, Zeraatpisheh M, Amirian-Chakan A Akbarzadeh A (2019) Soil erosion spatial prediction using digital soil mapping and RUSLE methods for Big Sioux River watershed. Soil Syst 3(3):43. https://doi.org/10.3390/soilsystems3030043

Wakiyama Y, Onda Y, Mizugaki S, Asai H, Hiramatsu S (2010) Soil erosion rates on forested mountain hillslopes estimated using ${ }^{137} \mathrm{Cs}$ and ${ }^{210} \mathrm{Pbex}$. Geoderma 159(1-2):39-52. https://doi.org/10.1016/j.geoderma.2010.06.012

Walling DE, Quine TA. Use of 137 Cs measurements to investigate soil erosion on arable fields in the UK: potential applications and limitations. J Soil Sci. 1991; 42:147e165.

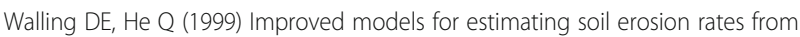
cesium-137 measurements. J Environ Qual 28(2):611-622. https://doi.org/1 0.2134/jeq1999.00472425002800020027x

Walling DE, He Q (2000) The global distribution of bomb-derived 137Cs reference inventories. Final report on IAEA technical contract 10361/RO-R1. University of Exeter, Exeter

Walling DE, He Q, Appleby PG (2002) Conversion models for use in soil-erosion, soil-redistribution and sedimentation investigations. In: Zapata F (ed) Handbook for the assessment of soil Erosion and sedimentation using environmental radionuclides. Kluwer Academic Publishers, Dordrecht, pp $111-164$

Wittenberg L, van der Wal H, Keesstra S, Tessler N (2020) Post-fire management treatment effects on soil properties and burned area restoration in a wildland-urban interface, Haifa fire case study. Sci Total Environ 716:135190. https://doi.org/10.1016/j.scitotenv.2019.135190

Zebari M, Grützner C, Navabpour P, Ustaszewski K (2019) Relative timing of uplift along the Zagros Mountain front flexure (Kurdistan region of Iraq): constrained by geomorphic indices and landscape evolution modeling. Solid Earth 10(3):663-682. https://doi.org/10.5194/se-10-663-2019

Zeraatpisheh M, Bakhshandeh E, Hosseini M, Alavi SM (2020) Assessing the effects of deforestation and intensive agriculture on the soil quality through digital soil mapping. Geoderma 363:114139. https://doi.org/10.1016/j. geoderma.2019.114139

Zhang X, Long Y, He X, Fu J, Zhang Y (2008) A simplified ${ }^{137} \mathrm{Cs}$ transport model for estimating erosion rates in undisturbed soil. J Environ Radioact 99(8): 1242-1246. https://doi.org/10.1016/j.jenvrad.2008.03.001

\section{Submit your manuscript to a SpringerOpen ${ }^{\circ}$ journal and benefit from:}

- Convenient online submission

- Rigorous peer review

- Open access: articles freely available online

- High visibility within the field

- Retaining the copyright to your article

Submit your next manuscript at $\boldsymbol{\nabla}$ springeropen.com 